\title{
Introducing an Advanced Building Information Modeling Course in Con- struction Management Programs
}

\section{Dr. Yilei Huang, South Dakota State University}

Dr. Yilei Huang is an Assistant Professor in the Department of Construction and Operations Management at South Dakota State University. His research interests include Building Information Modeling, reality capture, immersive virtual reality, and mixed reality. Dr. Huang is a Certified Professional of Autodesk Revit Architecture and holds a Master's and a Ph.D. degree in Civil Engineering from University of Kansas. 


\title{
Introducing an Advanced Building Information Modeling Course in Construction Management Programs
}

\begin{abstract}
Many construction management (CM) programs in the U.S. have introduced Building Information Modeling (BIM) in their curriculum due to the rapid adoption of BIM in the architecture, engineering and construction (AEC) industry. Previous research has revealed that most of the BIM courses offered in CM programs have mainly focused on 3D modeling skills as well as BIM applications in 4D scheduling and 5D estimating. While these topics appear to be important to apply BIM technology, students will not be able to fully understand the BIM process in a construction project without knowing the fundamental workflow of BIM. This paper presents a newly-developed BIM course which aims to help CM students better understand the BIM workflow and focuses on advanced uses of BIM in construction projects. The course is divided into three modules: BIM workflow, basic BIM applications, and advanced BIM applications. The BIM workflow module discusses how BIM is addressed in project delivery method, contract, the execution plan, and team building. The basic BIM applications module explains the typical BIM applications in 3D coordination, 4D scheduling, 5D estimating, logistics, visualization, etc. The advanced BIM applications module demonstrates the latest technology advances in the AEC industry that utilize BIM applications, including laser scanning, virtual reality, and mixed reality. This course will considerably improve CM students' understanding of BIM as a process instead of a modeling tools or software program and significantly broaden their insights into BIM beyond the existing 3D, 4D, and 5D applications. This paper will serve as a case study of an advanced level BIM course in CM programs.
\end{abstract}

\section{Introduction}

The rapid adoption of Building Information Modeling (BIM) in the architecture, construction, and engineering (AEC) industry has led to an increasing integration of BIM into construction management $(\mathrm{CM})$ programs in the U.S. Offering new BIM courses is one popular approach that many CM programs have employed to incorporate BIM contents into their curriculum. While introducing BIM in new courses is an effective method to quickly cover BIM components, the new courses often focus on specific modeling skills and analysis tools of BIM applications, such 4D scheduling and 5D estimating. Recent research, however, has argued that only knowing how to use BIM applications is not a true understanding of BIM and is in fact far from the expectations of being effective BIM users. It was also believed that without knowing the fundamental workflow of BIM, CM students will not be able to fully understand and utilize BIM to manage the construction process ${ }^{8}$.

This paper presents a newly-developed BIM course that aims to help CM students better understand the BIM workflow in a construction project and utilize BIM to manage the construction process. The course introduces advanced uses of BIM in construction projects and thus requires some BIM exposure in previous CM courses. The course is divided into three modules: BIM workflow, basic BIM applications, and advanced BIM applications. The BIM workflow module discusses how BIM is addressed in project delivery method, contract, the execution plan, and team building. The basic BIM applications module explains the typical BIM 
applications in 3D coordination, 4D scheduling, 5D estimating, logistics, visualization, etc. The advanced BIM applications module demonstrates the latest technology advances in the AEC industry that utilize BIM applications, including laser scanning, virtual reality, and mixed reality. This course will considerably improve CM students' understanding of BIM as a process instead of a modeling tool or software program and significantly broaden their insights into BIM beyond the existing 3D, 4D, and 5D applications. This paper will serve as a case study of an advanced level BIM course in CM programs.

\section{BIM in CM Education}

\section{From CAD to BIM}

Due to the standard use of paper drawings in the AEC industry, 2D computer-aided design (CAD) drafting has been traditionally used in CM education to facilitate the curriculum across various subjects including estimating quantity and cost, developing construction sequence and schedule, and analyzing site layout and safety risks ${ }^{1}$. While being widely used as a pedagogical tool, it often requires some degree of students' prior experience to interpret 2D CAD drawings since students have to perceptually visualize the components of a structure from lines and symbols in a drawing set and mentally combine them into a virtual structure. CM students with little or no previous experience often face challenges and have to spend more time interpreting 2D CAD drawings ${ }^{2}$.

Using BIM as a pedagogical tool in CM education can assist students in understanding the complexity of construction projects in both the process and product ${ }^{3,4}$. In addition, many CM students are aware of BIM as the emerging technology used in the industry and have the expectations of learning the latest and most essential paradigm in a CM program ${ }^{5}$. As a buzzword in the AEC industry, however, BIM sometimes misleads CM students to see it as a software program or an acronym for 3D design and modeling. The benefits of BIM in sharing and simulating construction information have often been overlooked in a CM curriculum ${ }^{6,7}$. Recent research has pointed out that only knowing how to use BIM applications is not a true understanding of BIM and is in fact far from the expectations of being effective BIM users. Without knowing the fundamental workflow of BIM, CM students will not be able to fully understand and utilize BIM to manage the construction process ${ }^{8}$.

\section{BIM Adoption}

To better equip students with the capabilities demanded by the AEC industry, many CM programs have incorporated BIM contents into their curriculum ${ }^{9}$. Various teaching methods and course layout have been used in different $\mathrm{CM}$ programs to introduce $\mathrm{BIM}^{10,11,12}$. In general, most CM programs offer BIM in one to three courses and limit its coverage within a single discipline ${ }^{12,13}$. The implementation strategies include introducing BIM as standalone courses, utilizing cross-discipline BIM courses, adding BIM labs in capstone/project courses, and integrating BIM into existing courses ${ }^{14}$.

Pavelko and Chasey performed a survey of 59 construction programs that were members of the Associated Schools of Construction (ASC) and the American Council for Construction 
Education (ACCE). The results indicated that 70\% of the respondents had covered BIM in their curriculum, of which most were on 3D coordination (82\%), about half on 4D scheduling (46\%), and a third on 5D estimating $(35 \%)^{7,15}$. Becerik-Gerber et al. expanded the pool to $26 \mathrm{CM}$ programs that were members of the Accreditation Board for Engineering and Technology (ABET). The findings showed that $60 \%$ of them had some BIM components in their curriculum, mostly in one or two elective courses ${ }^{4,16}$, and the most-taught topics were constructability, scheduling, estimating, design, and visualization ${ }^{7,16}$. Joannides et al. surveyed 70 construction programs that were ACCE members and received 35 responses. The results suggested that $83 \%$ of them had included BIM in their curriculum with the majority (55\%) in one to two courses 9 . The most popular topics were still 3D coordination (37\%), 4D scheduling (25\%), and 5D estimating $(20 \%)^{9}$.

\section{BIM Courses}

Offering new BIM courses is one popular approach that many CM programs have employed to incorporate BIM contents into their curriculum. One typical solution is to have an introductory BIM course replace an existing lower level CAD course, such as Construction Graphical Communication or Construction Information Technology ${ }^{13}$, 17. This is viable because students no longer need CAD drafting once they use BIM since 2D drawings can be generated directly from a 3D BIM model. Due to the course conversion, these introductory BIM courses focus mainly on specific modeling skills ${ }^{9,18}$. The other solution is to offer a new junior- or senior-level elective BIM course as an addition to the CM curriculum. These elective BIM courses often focus on analysis tools of BIM applications, such 3D coordination, 4D scheduling, and 5D estimating, and use model-based project to demonstrate the use of BIM in various CM subjects ${ }^{11,12}$.

The CM program at Arizona State University offered Introduction to BIM as a 1-credit computer application course to teach the concept of BIM process and applications of BIM software ${ }^{6}$. The program further offered a 1-credit BIM lab to accompany the CM capstone course Project Management. The BIM lab covered a range of BIM-related CM topics including site logistics visualization, model-based estimating, $4 \mathrm{D}$ scheduling, and clash detection using a variety of commercial packages such as Revit, Navisworks, SketchUp, Bluebeam Revu, and DESTINI Profiler. The capstone course itself also incorporated BIM contents on developing a BIM Execution Plan ${ }^{7}$.

The CM program at University of Texas at San Antonio offered BIM for Construction Management as a 3-credit elective course for junior and senior students who had completed CM core courses. As the only BIM course in the curriculum, it covered a wide variety of BIM topics including design and visualization, model based quantity take-off and estimating, and 4D scheduling, clash detection, and constructability. The course contained lecture sessions to introduce BIM concepts, execution plans, implementation, case studies, and software demonstration, and included lab sessions to provide hands-on practice on Revit (Architecture, Structure, MEP), Navisworks, as well as SketchUp and Primavera P6. The course focused on basic modeling skills, understanding of database, as well as trade coordination with different platforms ${ }^{19}$. 
Some CM programs chose to offer a BIM module or workshops within an existing CM course instead of offering a complete new course as an alternative approach. The CM program at Colorado State University developed a BIM module within a structures course to present the capabilities of BIM software and other analysis programs, including 3D interactive animations, material schedules and quantity takeoff, material and labor cost estimates, and construction sequence $^{20}$. The CM program at California State University, Chico included seven one-hour BIM workshops in the Construction Methods Analysis course and had industry representatives teach various BIM tools, i.e., SketchUp, Revit, Navisworks, and Solibri, on related CM topics including site layout, model analysis, structural steel sequencing, clash detection, and constructability $^{21}$.

The CM program at University of North Carolina at Charlotte proposed a workflow for a BIM course in a CM curriculum. The workflow suggested that the course should be a senior-level course for students who had completed CM core courses such as estimating, scheduling, and project management. The proposed workflow contained five BIM components, namely 3D modeling, cost estimating, scheduling and control, project administration, and contract documents, and covered the two major BIM packages, Autodesk Revit (Architecture, Structure, MEP) and Navisworks, and Vico Virtual Construction Software Suite (Constructor, Estimator, Cost Manager, 5D Presenter $)^{22}$.

In general, while introducing BIM in new courses is an effective method to quickly cover BIM components, these new courses often focus on specific modeling skills and analysis tools of BIM applications, such 4D scheduling and 5D estimating. In order to effectively utilize BIM tools to manage the construction process, fully understanding the BIM workflow in a construction project is of equal importance to CM students ${ }^{8}$. Some existing BIM courses ignored the BIM workflow and as a result, CM students had seen BIM simply as 3D design and modeling or just as a software program without recognizing its benefits in sharing and simulating construction information ${ }^{6,7}$.

\section{The Advanced BIM Course}

\section{Overview}

The CM program at South Dakota State University developed a new BIM course that aims to help CM students better understand the BIM workflow in a construction project and utilize BIM to manage the construction process. The CM curriculum at South Dakota State University has already integrated BIM contents in several core and elective courses from lower level to upper level, including Construction Graphics, Building Methods and Systems, Residential

Construction, and Construction Planning and Scheduling, and thus most CM students have basic exposure to and understanding of BIM. The curriculum, however, does not have a course that introduces the BIM workflow in a construction project or applies BIM in project-based case studies. As a result, the CM program decided to offer a new advanced BIM course to emphasize the BIM workflow, refresh on basic BIM applications in project-based scenarios, and introduce advanced uses of BIM that are trending in the AEC industry. Designed as an upper level elective course, it requires CM students to have completed certain lower level courses with the integration of BIM to obtain a basic understanding of the concept, modeling skills, and some 
fundamental applications. The course is divided into three modules: BIM workflow, basic BIM applications, and advanced BIM applications. The BIM workflow module discusses how BIM is addressed in project delivery method, contract, the execution plan, and team building. The basic BIM applications module explains the typical BIM applications in 3D coordination, 4D scheduling, 5D estimating, logistics, visualization, etc. The advanced BIM applications module demonstrates the latest technology advances in the AEC industry that utilize BIM applications, including laser scanning, virtual reality, and mixed reality. This course will considerably improve CM students' understanding of BIM as a process instead of a modeling tool or software program and significantly broaden their insights into BIM beyond the existing 3D, 4D, and 5D applications.

\section{Course Objectives}

The course objectives were developed to match the CM curriculum needs in BIM contents and in the meanwhile align with the six levels of cognitive learning process in Bloom's Taxonomy. Anderson et al. revised the original taxonomy and defined the cognitive learning process as "remember, understand, apply, analyze, evaluate, and create" from lower- to higher-order thinking skills ${ }^{23}$. As shown in Table 1, five course objectives were developed for the three course modules. The BIM workflow module aims for Objective 1 "Understand BIM" and Objective 2 "Describe Levels of Development (LOD) and BIM Execution Plan," both of which belong to lower-level cognitive learning process "remember" and "understand." The basic BIM applications module aims for Objective 3 "Perform BIM applications," which covers mid-level cognitive learning process "apply" and "analyze," and Objective 4 "Apply BIM in project" which contains higher-level cognitive learning process "evaluate" and "create." The advanced BIM applications module aims for Objective 5 "Demonstrate BIM advances," covering lower- to mid-level cognitive learning process "understand" and "apply."

Table 1. Course Objectives Associated with Bloom's Taxonomy

\begin{tabular}{llll}
\hline \multicolumn{1}{c}{ Course Objective } & Course Module & Bloom's Taxonomy \\
\hline 1. $\begin{array}{l}\text { Understand the concept of BIM and its } \\
\text { applications in construction management }\end{array}$ & BIM workflow & $\begin{array}{l}\text { Remember and } \\
\text { understand }\end{array}$ \\
\hline $\begin{array}{l}\text { 2. } \\
\text { Describe different Levels of Development } \\
\text { (LOD) and components of BIM Execution Plan }\end{array}$ & BIM workflow & $\begin{array}{l}\text { Remember and } \\
\text { understand }\end{array}$ \\
\hline 3. & $\begin{array}{l}\text { Perform model-based planning, estimating, } \\
\text { scheduling, coordination, and visualization }\end{array}$ & $\begin{array}{l}\text { Basic BIM } \\
\text { applications }\end{array}$ & Apply and analyze \\
\hline 4. $\begin{array}{l}\text { Apply BIM in project-based scenarios to solve } \\
\text { CM problems }\end{array}$ & $\begin{array}{l}\text { Basic BIM } \\
\text { applications }\end{array}$ & Evaluate and create \\
\hline 5. $\begin{array}{l}\text { Demonstrate the latest BIM advances in the } \\
\text { AEC industry }\end{array}$ & $\begin{array}{l}\text { Advanced BIM } \\
\text { applications }\end{array}$ & $\begin{array}{l}\text { Understand and } \\
\text { apply }\end{array}$ \\
\hline
\end{tabular}

\section{Course Layout}

Table 2 presents the course topics associated with their respective objective in each course module. The course topics were scheduled based on a standard 15-week semester with 2 weeks reserved for exams, presentations, and holidays, which leaves 13 full weeks of classroom 
instruction. The course topics include a combination of lectures, computer labs, demonstrations, and hands-on equipment operation.

Table 2. Course Topics in Each Course Module

\begin{tabular}{|c|c|c|c|}
\hline $\begin{array}{l}\text { Course } \\
\text { Module }\end{array}$ & Course Objective & Course Topics & $\begin{array}{c}\text { Course } \\
\text { Schedule }\end{array}$ \\
\hline \multirow{6}{*}{$\begin{array}{l}\text { BIM } \\
\text { workflow }\end{array}$} & \multirow[t]{3}{*}{ 1. Understand BIM } & The Value of BIM & Week 1 \\
\hline & & Delivery Methods for BIM & Week 2 \\
\hline & & Contract Types/BIM Contract & Week 2 \\
\hline & \multirow{3}{*}{$\begin{array}{l}\text { 2. Describe LOD and } \\
\text { BIM Execution Plan }\end{array}$} & Levels of Development (LOD) & Week 3 \\
\hline & & BIM Execution Plan & Week 3 \\
\hline & & BIM Team and BIM Kickoff Meeting & Week 4 \\
\hline \multirow{10}{*}{$\begin{array}{l}\text { Basic BIM } \\
\text { applications }\end{array}$} & \multirow{5}{*}{$\begin{array}{l}\text { 3. Perform BIM } \\
\text { applications }\end{array}$} & Model-Based Estimating & Week 5 \\
\hline & & Site Logistics & Week 6 \\
\hline & & BIM Scheduling & Week 7 \\
\hline & & Construction Coordination & Week 8 \\
\hline & & Document Control & Week 9 \\
\hline & \multirow[t]{5}{*}{ 4. Apply BIM in project } & Revit Lab: Model-Based Estimating & Week 5 \\
\hline & & Navisworks Lab: Site Logistics Plan & Week 6 \\
\hline & & Navisworks Lab: 4D Scheduling & Week 7 \\
\hline & & Navisworks Lab: Clash Detection & Week 8 \\
\hline & & Bluebeam Revu Lab: Doc Control & Week 9 \\
\hline \multirow{4}{*}{$\begin{array}{l}\text { Advanced } \\
\text { BIM } \\
\text { applications }\end{array}$} & \multirow{4}{*}{$\begin{array}{l}\text { 5. Demonstrate BIM } \\
\text { advances }\end{array}$} & ReCap Lab: Laser Scanning & Week 10 \\
\hline & & Stingray Lab: Real-time Walkthrough & Week 11 \\
\hline & & VR Experience with Rift/Vive & Week 12 \\
\hline & & MR Experience with HoloLens & Week 13 \\
\hline
\end{tabular}

\section{BIM Workflow Module}

The BIM workflow module takes the first four weeks of the course covering the most important topics pertaining to how to start a construction project with BIM included as a management tool, as detailed in Table 2. These topics have often been overlooked when BIM is introduced in a CM curriculum, but are actually a critical component of knowledge for students to understand the role of BIM in a construction project. The module starts with an introduction of the value of BIM, followed by selecting the appropriate project delivery method and contract for BIM. Design-build and CM at risk as well as the new Integrated Project Delivery method have been considered to have the capability of leveraging BIM tools and practices ${ }^{24}$. Professional organizations such as American Institute of Architects (AIA), Associated General Contractors of America (AGC), and Design-Build Institute of America (DBIA) have specific BIM contracts available for commercial use (AIA E203, ConsensusDocs 301, and DBIA E-BIMWD) ${ }^{24}$. The module further explains in detail the Levels of Development (LOD) and the components of a BIM Execution Plan, followed by different roles in a BIM team and what to expect in the BIM kickoff meeting. Overall, the BIM workflow module forms the foundation of the course and is critical for CM students to fully understand the BIM process in a construction project. 


\section{Basic BIM Applications Module}

As introduced earlier, the CM curriculum at South Dakota State University has already integrated BIM contents in several courses, and thus most CM students have had exposure to basic BIM tools. As a result, the basic BIM application module focuses on refreshing on these basic applications by applying them in project-based scenarios. The basic BIM applications module follows the BIM workflow module and takes the next five weeks out of the 13-week course schedule, as presented in Table 2. The module covers the most used BIM applications including model-based estimating and scheduling, site logistics, construction coordination, document control, etc. The module features a one-hour lecture session plus a two-hour lab session in a week for each topic. The lecture session aims to refresh on the use and benefits of the applications as well as to introduce the project-based scenario, and the lab session focuses on instructor demonstration and students hands-on practice on the scenario. Lab sessions include an Autodesk Revit lab on model-based estimating, three Autodesk Navisworks labs on site logistics plan, 4D scheduling, and clash detection, respectively, and a Bluebeam Revu lab on document control. The BIM software used in the lab sessions are the most popular commercial packages that are being used widely in the AEC industry. When students complete the first two modules, they will be well-equipped to meet the expectations of future employers as an effective BIM user.

\section{Advanced BIM Applications Module}

The advanced BIM applications module aims to introduce and demonstrate the latest technology advances in the AEC industry that utilize BIM applications. This module follows the basic BIM applications module and take the last four weeks of the course. Based on the research areas of the CM faculty at South Dakota State University, four topics are selected for this module including laser scanning, real-time walkthrough, virtual reality (VR), and mixed reality (MR), as shown in Table 2.

1) Laser scanning. The CM faculty have access to a FARO Focus ${ }^{3 \mathrm{D}}$ laser scanner through university collaboration and have employed the laser scanner in several research projects. The topic first introduces the uses of benefits of laser scanning in a construction project, then provides hands-on practice to students on setting up and operating the laser scanner, followed by a lab session to process the captured point clouds. The lab session features a workflow of first combining multiple scans with FARO Scene, then editing the combined scan with Autodesk ReCap, and finally modeling architectural and structural designs around the scan with Autodesk Revit.

2) Real-time walkthrough. Traditional BIM walkthroughs are created with either Revit, Navisworks, or Synchro as videos where the audience follow the view of the video and thus have no control over what is being presented. Autodesk introduced a new 3D game engine, Stingray, in 2015 which is able to create real-time design visualizations. The game engine is particularly beneficial to the AEC industry in that it provides a seamless workflow to bring a design directly from Revit to 3ds Max and then to Stingray. A building model is first imported from Revit to 3ds Max to optimize its visual accuracy, and then deployed with Stingray as an interactive game experience for a real-time walkthrough ${ }^{25}$. Alternatively, Autodesk Live, introduced in 2016, offers similar interactive visualization through cloud services. This topic in the advanced BIM 
applications module uses lab sessions to demonstrate the workflow of Revit to $3 \mathrm{ds}$ Max to Stingray for a real-time walkthrough.

3) Virtual reality (VR). VR as a buzzword in 2016 has quickly received attention in the AEC industry. In fact, VR was employed in the industry as early as 2013 in Mortenson's Pegula Ice Arena and Sanford Fargo Medical Center projects ${ }^{26,27}$. The CM faculty has a Virtual Design and Construction (VDC) Lab equipped with an Oculus Rift, an HTC Vive, and two VR-ready workstation computers, and these VR equipment have been used in research projects to develop VR applications. The traditional game engine Unity has provided a VR project template for Oculus Rift and the new game engine Stingray has provided a similar template for HTC Vive. With the provided project templates, a Revit model can be converted into a VR project and be viewed with an immersive experience. Alternatively, other commercial applications are available to convert BIM models into VR models directly, such as IrisVR and InsiteVR, for both computer-based VR equipment and mobile VR equipment. This topic in the advanced BIM applications module uses student participation to demonstrate VR experience with Oculus Rift and HTC Vive using a Revit model converted by both Stingray and IrisVR.

4) Mixed reality (MR). The concept of MR has been brought to attention in the AEC industry since Microsoft released the HoloLens in 2016. MR is different than augmented reality (AR) in that AR applications present augmented information based on physical objects while MR applications combine virtual objects and physical objects in the same environment. The CM faculty has two units of HoloLens in the VDC Lab for research and educational projects. Unity used to provide a specific HoloLens version for developing MR applications and then have included it in its later updates. Alternatively, MR applications for BIM are also available. 3D Viewer Beta, developed and offered freely by Microsoft, enables BIM users to bring BIM models into MR with some prior conversion efforts in Revit and Navisworks. Trimble released the SketchUp Viewer in late 2016 as the first extensible commercial HoloLens application which enables collaboration and coordination in MR between BIM users, as illustrated in Figure 1. This topic in the advanced BIM applications module uses student participation to demonstrate MR experience with Microsoft HoloLens using the same Revit model converted by 3D Viewer Beta.

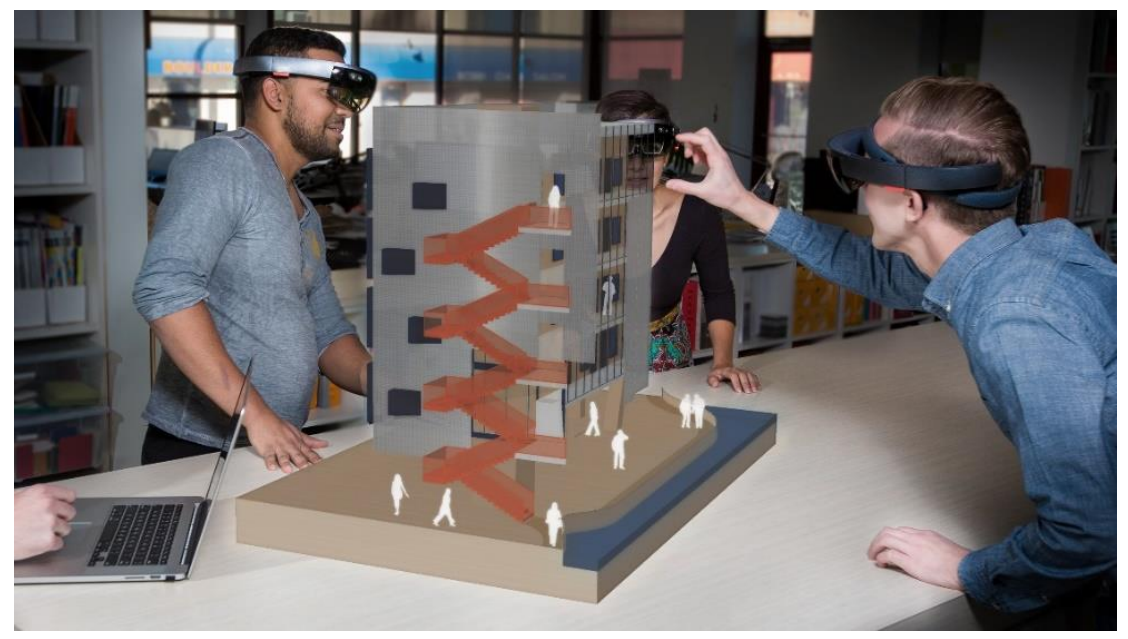

Figure 1. Collaboration through Trimble SketchUp Viewer Using Microsoft HoloLens (picture obtained from sketchup.com for demonstration purpose) 


\section{Course Assessment}

The course uses a weighted grading system with six categories including participation (15\%), three assignments (15\%), seven labs $(20 \%)$, one exam (15\%), final project $(20 \%)$, and final presentation $(15 \%)$. Labs and the final project weight $5 \%$ more than the other four categories because they include more tasks, cover longer duration of the course, and require more efforts to complete. Participation, assignments, exam, and the final presentation weight the same as they contribute roughly the same to the course and require a similar amount of efforts. Participation is graded specifically for hands-on operations such as laser scanning, VR and MR experience.

Each course objective is assessed against the assessment criteria presented in Table 3 by at least two assessment methods. Objective 1 "Understand BIM" is assessed by two assignments and the exam to evaluate students' ability to define BIM, describe the benefits of BIM, and identify the appropriate delivery methods and contract for BIM. Objective 2 "Describe LOD and BIM Execution Plan" is assessed by one assignment, the final project, and the final presentation to evaluate students' ability to differentiate LODs, prepare a BIM Execution Plan from a template, and form an effective BIM team to present the plan. Objective 3 "Perform BIM applications" is assessed by the exam and five labs to evaluate students' ability to describe different BIM applications in CM, identify the BIM tools needed, and perform project analysis with BIM tools. Objective 4 "Apply BIM in project" is assessed by the same five labs, the final project, and the final presentation to evaluate students' ability to justify the use of BIM in project-based scenarios and apply BIM to solve real-world CM problems. Objective 5 "Demonstrate BIM advances" is assessed by participation of hands-on operations and two labs to evaluate students' ability to describe the latest advances in BIM and operate the advanced equipment effectively.

Table 3. Assessment Methods and Criteria for Each Course Objective and Course Topics

\begin{tabular}{|c|c|c|c|}
\hline Course Objective & Course Topics & $\begin{array}{c}\text { Assessment } \\
\text { Methods }\end{array}$ & Assessmen \\
\hline $\begin{array}{l}\text { 1) Unders } \\
\text { BIM }\end{array}$ & $\begin{array}{l}\text { BIM } \\
\text { Methods }\end{array}$ & $\begin{array}{l}\text { Assignments } \\
\text { and exam }\end{array}$ & $\begin{array}{l}\text { Ability to define BIM, describe } \\
\text { its benefits, and identify BIM } \\
\text { delivery methods and contract }\end{array}$ \\
\hline $\begin{array}{l}\text { 2) Desc } \\
\text { and } \mathrm{E} \\
\text { Exec }\end{array}$ & $\begin{array}{l}\text { Levels of Development } \\
\text { BIM Execution Plan } \\
\text { BIM Team and Meeting }\end{array}$ & $\begin{array}{l}\text { ents, } \\
\text { and } \\
\text { tion }\end{array}$ & $\begin{array}{l}\text { Ability to differentiate LODs, } \\
\text { prepare a BIM Execution Plan, } \\
\text { and form an effective BIM team }\end{array}$ \\
\hline 3) $\begin{array}{l}\text { Perform BIM } \\
\text { applications }\end{array}$ & $\begin{array}{l}\text { BIM Estimating } \\
\text { Site Logistics } \\
\text { BIM Scheduling } \\
\text { Coordination } \\
\text { Document Control }\end{array}$ & $\begin{array}{l}\text { Exam and } \\
\text { labs }\end{array}$ & $\begin{array}{l}\text { Ability to describe different } \\
\text { BIM applications in CM, } \\
\text { identify the BIM tools needed, } \\
\text { and perform project analysis } \\
\text { with BIM tools }\end{array}$ \\
\hline $\begin{array}{l}\text { 4) Apply BIM in } \\
\text { project }\end{array}$ & $\begin{array}{l}\text { Revit Lab } \\
\text { Navisworks Labs } \\
\text { Bluebeam Revu Lab } \\
\end{array}$ & $\begin{array}{l}\text { Labs, } \\
\text { project, and } \\
\text { presentation }\end{array}$ & $\begin{array}{l}\text { Ability to justify the use of BIM } \\
\text { in project-based scenarios and } \\
\text { apply BIM to solve problems }\end{array}$ \\
\hline $\begin{array}{l}\text { 5) Demonstrate } \\
\text { BIM advances }\end{array}$ & $\begin{array}{l}\text { Laser Scanning } \\
\text { Real-time Walkthrough } \\
\text { VR and MR Experience }\end{array}$ & $\begin{array}{l}\text { Participation } \\
\text { and labs }\end{array}$ & $\begin{array}{l}\text { Ability to describe the latest } \\
\text { advances in BIM and operate } \\
\text { the equipment effectively }\end{array}$ \\
\hline
\end{tabular}




\section{Course Evaluation}

This course is currently being offered for the first time, and as a result, inadequate information on student performance and feedback have been collected to evaluate the course. Future research will continue on course evaluation via the following methods:

1) Monitor student performance in each course objective. The student performance goal of the CM program is that $80 \%$ of student achieve $70 \%$ or above grade. The course will adopt this goal for each course objective and monitor the percentages of students meeting the goal.

2) Conduct student surveys at the end of the semester. The survey includes a unified student rating of instruction (SROI) used across the university and a questionnaire specifically designed for this course. The SROI will be used to track the performance of course materials and instruction. The questionnaire will record students' ratings and comments on each topic of the course, including the difficulty of lecture and lab materials, the readiness of lab programs and equipment, the shortcomings and potential improvements, etc. The feedback of questionnaires will be used to improve future course offerings.

3) Compare and analyze the evaluation results of both student performance and student surveys in each course offering. The comparison and analyses will be used to track the course performance over time and improve overall course quality.

\section{Conclusions}

As the rapid adoption of BIM in the AEC industry, many CM programs in the U.S. have introduced BIM in their curriculum to meet industry expectations. A review of current literature suggested that existing BIM courses often focused on specific modeling skills and analysis tools of BIM applications while overlooking the fundamental workflow of BIM in a construction project. Recent studies have also argued that only knowing how to use BIM applications is not a true understanding of BIM and is in fact far from the expectations of being effective BIM users. This paper presents a newly-developed BIM course that aims to help CM students better understand the BIM workflow in a construction project and utilize BIM to manage the construction process. The course focuses on advanced uses of BIM in construction projects and includes three modules: BIM workflow, basic BIM applications, and advanced BIM applications. Five course objectives were developed to match the CM curriculum needs in BIM contents and align with the six levels of cognitive learning process in Bloom's Taxonomy. In each course module, specific course topics were introduced and associated with a course objective. Course assessment methods and criteria were detailed for each course objective, and course evaluation plan was briefly explained for future research. This paper will serve as a case study of an advanced level BIM course in CM programs.

\section{References}

1. Zolfagharian, S., Gheisari, M., Irizarry, J., and Meadati, P. (2013). Exploring the Impact of Various Interactive Displays on Student Learning in Construction Courses. Proceedings of the $120^{\text {th }}$ ASEE Annual Conference and Exposition, Atlanta, GA, June 23-26, 2013. 
2. Irizarry, J., Meadati, P., Barham, W.S., and Akhnoukh, A. (2012). Exploring Applications of Building Information Modeling for Enhancing Visualization and Information Access in Engineering and Construction Education Environments. International Journal of Construction Education and Research, 8(2), 119-145.

3. Boon, J. and Prigg, C. (2011). Releasing the Potential of BIM in Construction Education. Proceedings of the Management and Innovation for Sustainable Build Environment, Amsterdam, Netherlands, June 20-23, 2011.

4. Pikas, E., Sacks, R., and Hazzan, O. (2013). Building Information Modeling Education for Construction Engineering and Management. II: Procedures and Implementation Case Study. Journal of Construction Engineering and Management, 139(11), 05013002.

5. Nawari, N., Chichugova, T., Mansoor, S., and Delfin, L. (2014). BIM in Structural Design Education. Proceedings of the 2014 International Conference on Computing in Civil and Building Engineering, Orlando, FL, June 23-25, 2014, pp 2143-2150.

6. Ghosh, A., Parrish, K., and Chasey, A.D. (2013). From BIM to Collaboration: A Proposed Integrated Construction Curriculum. Proceedings of the $120^{\text {th }}$ ASEE Annual Conference and Exposition, Atlanta, GA, June 23-26, 2013.

7. Ghosh, A., Parrish, K., and Chasey, A.D. (2015). Implementing a Vertically Integrated BIM Curriculum in an Undergraduate Construction Management Program. International Journal of Construction Education and Research, 11(2), 121-139.

8. Lee, N. and Dossick, C.S. (2012). Leveraging Building Information Modeling Technology in Construction Engineering and Management Education. Proceedings of the $119^{\text {th }}$ ASEE Annual Conference and Exposition, San Antonio, TX, June 10-13, 2012.

9. Joannides, M.M., Olbina, S., and Issa, R.R.A. (2012). Implementation of Building Information Modeling into Accredited Programs in Architecture and Construction Education. International Journal of Construction Education and Research, 8(2), 83-100.

10. Barison, M.B. and Santos, E.T. (2010a). An Overview of BIM Specialists. Proceedings of the 2010 International Conference on Computing and Civil and Building Engineering, Nottingham, UK, June 30 - July 2, 2010.

11. Sacks, R. and Barak, R. (2010). Teaching Building Information Modeling as an Integral Part of Freshman Year Civil Engineering Education. Journal of Professional Issues in Engineering Education and Practice, 136(1), 3038.

12. Sacks, R. and Pikas, E. (2013). Building Information Modeling Education for Construction Engineering and Management. I: Industry Requirements, State of the Art, and Gap Analysis. Journal of Construction Engineering and Management, 139(11), 04013016.

13. Barison, M.B., and Santos, E.T. (2010b). Review and Analysis of Current Strategies for Planning a BIM Curriculum. Proceedings of the $27^{\text {th }}$ CIB W78 International Conference, Cairo, Egypt, November 16-19, 2010.

14. Huang, Y. (2016). Integrating Building Information Modeling in Existing Courses: A Systematic Framework for Undergraduate Construction Management Programs. Proceedings of the $123^{\text {rd }}$ ASEE Annual Conference and Exposition, New Orleans, LA, June 26-29, 2016.

15. Pavelko, C. and Chasey, A. (2010). Building Information Modeling in Today's University Undergraduate Curriculum. Proceedings of the 2010 Ecobuild America, Washington, D.C., December 6-10, 2010.

16. Becerik-Gerber, B., Gerber, D.J., and Ku, K. (2011). The Pace of Technological Innovation in Architecture, Engineering, and Construction Education: Integrating Recent Trends into the Curricula. Journal of Information Technology in Construction, 16, 411-432.

17. Taylor, M., Liu, J., and Hein, M. (2008). Integration of Building Information Modeling (BIM) into an ACCE Accredited Construction Management Curriculum. Proceedings of the $44^{\text {th }}$ ASC Annual International Conference, Auburn, AL, April 2-5, 2008.

18. Lee, N. and Hollar, D.A. (2013). Probing BIM Education in Construction Engineering and Management Programs Using Industry Perceptions. Proceedings of the $49^{\text {th }}$ ASC Annual International Conference, San Luis Obispo, CA, April 10-13, 2013.

19. Liu, R. and Hatipkarasulu, Y. (2014). Introducing Building Information Modeling Course into a Newly Developed Construction Program with Various Student Backgrounds. Proceedings of the $121^{\text {st }}$ ASEE Annual Conference and Exposition, Indianapolis, IN, June 15-18, 2014.

20. Richards, E.L. and Clevenger, C.M. (2011). Interoperable Learning Leveraging Building Information Modeling (BIM) in Construction Management and Structural Engineering Education. Proceedings of the $47^{\text {th }}$ ASC Annual International Conference, Omaha, NE, April 6-9, 2011.

21. Gier, D.M. (2015). Integrating Building Information Modeling (BIM) into Core Courses within a Curriculum: A Case Study. International Journal of Engineering Research and General Science, 3(1), 528-543. 
22. Chen, D. and Gehrig, G. B. (2011). Implementing Building Information Modeling in Construction Engineering Curricula. Proceedings of the $118^{\text {th }}$ ASEE Annual Conference and Exposition, Vancouver, BC, Canada, June 26-29, 2011.

23. Anderson, L. W., Krathwohl, D. R., Airasian, P. W., Cruikshank, K. A., Mayer, R. E., Pintrich, P. R., Raths, J., and Wittrock, M. C. (2001). A Taxonomy for Learning, Teaching, and Assessing: A Revision of Bloom's Taxonomy of Educational Objectives, Complete Edition. Pearson, New York City, NY. ISBN: 9780321084057.

24. Hardin, B. and McCool, D. (2015). BIM and Construction Management: Proven Tools, Methods, and Workflows, $2^{\text {nd }}$ Edition. John Wiley \& Sons, Indianapolis, IN. ISBN: 978-1118942765.

25. Easy Workflow from BIM to Interactive. URL: http://www.autodesk.com/products/stingray/features/designvisualization/easy-workflow-from-bim-to-interactive. Retrieved January 2017.

26. Cupp, T. (2015). Simulating Healthcare Spaces through Virtual Reality. Healthcare Design, May 20, 2015.

27. Muret, D. (2016). Why Builder Mortenson Has Long Employed VR Technology. SportsBusiness Journal, June 20, 2016. 